\title{
Review
}

\section{Les Aveux de la chair. Vol. 4 of L'Histoire de la sexualité}

\author{
Michel Foucault \\ Éditions Gallimard, Paris, 2018, 426 pp. \\ ISBN: 9782072700347
}

Contemporary Political Theory (2020) 19, S192-S196. https://doi.org/10.1057/s41296019-00333-z; Published online 11 July 2019

Michel Foucault's History of Sexuality series has long perplexed readers with the Greco-Roman detour that comes after the first volume. By contrast, his interviews on sexuality from the same period on are remarkably direct. In a 1982 interview, Michel Foucault asks, 'How can a relational system be reached through sexual practices? Will it require the introduction of a diversification different from the ones due to social class, differences in profession and culture, a diversification that would also be a form of relationship and would be a "way of life"?' (1997a, pp. 137-138). Other interviews from this period likewise experiment with the language of seeking new 'relational modes' that would back away from the nineteenth century's institutionalized model of heterosexuality that is held in place through the institutions of family, marriage, medicine, and law. The posthumously published Aveux de la chair effectively takes up these questions and queries: How have sexuality, power, and identity become entwined in the modern desiring subject - and with what limits to sexual relations, broadly speaking?

These preoccupations with historicizing the subject frame Foucault's Aveux de la chair, the long-awaited unpublished fourth volume of the History of Sexuality series. The title, which translates as Confessions of the Flesh, intimates something of the discursive stakes of the argument: the book surveys the practices that slowly bind what come to be confessional speech practices to earlier Christian preoccupations with flesh and concupiscence. Aveux thus sits at the crux of Foucault's concerns with sexuality and truth-telling in the ancient world. The text proceeds genealogically through dusty texts of the early Church fathers, including Clement of Alexandria, Cassian, John Chrysostom, Tertullian, and Augustine of Hippo. Its substantive focus is not yet that of sexuality (a term that Foucault usually reserves for the nineteenth century junction of confession and medicine that focus on an objectified self). Instead, Foucault analyzes the conjoinment of truth-telling practices and sexual relations in the Christian problem of concupiscence. Significantly, aveu can be translated as either 'confession' or 'avowal', depending

(C) 2019 Springer Nature Limited. 1470-8914 Contemporary Political Theory Vol. 19, S3, S192-S196 www.palgrave.com/journals 
on context. Foucault seeks no less than to investigate how the spiritual subject of veridiction became connected to the juridical subject of law.

Sexuality thus conceived requires a genealogy of desire and the desiring subject that could explain the junction of subjectivity and truth-telling. In Aveux, the reigning concept is flesh and the accompanying problems of concupiscence, or the inclination towards sin (and especially sensual desire) that is the residue of original sin. Spanning the second to the fifth centuries, Aveux seeks to trace two crucial changes: first, changes in modes of truth-telling that permit a subject of desirous knowledge to appear later in the nineteenth century; and the second, the attachment of this truth-telling to increasingly social questions refracted onto flesh and sexuality. The book is divided into three parts (titled by the volume's editor): first, the 'formation of a new experience'; second, the experience of 'being virgin'; and finally, the experience of 'being married'.

Within the first section, Foucault bridges to his earlier work on ancient truthtelling practices. Moving from Seneca to Cassian to John Chrysostom, he tells of the emergence of an expressive performance of baptism and penitence, their entwinement, and their absorption into what will much later become recognizable as confessional speech. Organized around three moments of evaluation interrogatory inquiry (enquête), exorcism and its tests (épreuves), and a confession of sins - baptism offers an expressive truth of one's relationship to God (p. 57), and is more demonstrative than verbal (p. 67). It is part of a larger 'spiritual combat' understood as a preparation against the Enemy, or Satan (pp. 75-77), and the penitential rites of exomologesis are more a 'faire vrai' (making-true) than a 'direvrai' or truth-telling (p. 105). Adopted from the ancient Greeks, the examination of conscience, or exagoreusis, gradually comes to offer a new relation to the self, and a new form of truth-telling. Exagoreusis moves away from self-mastery, but is not yet the confession of failed responsibilities or transgressive acts. Instead, it works to discover truths for oneself, by steadying the inconstancies of shadowy illusion and false appearances. Foucault clarifies that with such confessions, 'We're in the realm not of the jurisdiction of acts for which one takes responsibility, but the veridiction of secrets within oneself of which one is ignorant' (p. 144). Although confession has its roots in monasticism, the real question it raises is how its practices of mortification - this new 'form of experience' - come to spread beyond those already devoted to regulating desire broadly understood.

To answer this question, in the second and third sections of Aveux Foucault turns to practices of virginity and marriage, both of which become extensions of this ceaseless work of mortification in contexts beyond the monastery. In the first two centuries of Christianity, virginity was less a principle of abstention or taboo than an ascetic practice of sexual renunciation. Virginity becomes defined as a spiritual movement; it organizes as a type of relation to self, one that opens onto a domain of internal knowledge, and inscribes itself in a relation of power with another (p. 215). Flesh becomes infused with spirit, and a new kind of subjectivation is born (p. 213).

(c) 2019 Springer Nature Limited. 1470-8914 Contemporary Political Theory Vol. 19, S3, S192-S196 S193 
Drawing largely on John Chrysostom, Foucault argues against the common association of Christian marriage with the injunction to procreate. If virginity was a fleshy, expressive form of veridiction, then matrimonial practices are jurisdictional. They regulate the economy of concupiscence, and thus marriage must help both parties temper their desires for other ways of life. Somewhat surprisingly, Foucault argues that, '[T]he obligations that [John Chrysostom] stipulates for spouses constitutes a sort of political equality when it comes to sexual relations; the rights of one stipulate the duties (devoirs) of the other' (p. 275). This system of obligations is not founded on symmetry in decision-making or a community of the will: 'Its form is that of a political equality. Its foundation is that of propriety' ( $\mathrm{p}$. 275). Both spouses appropriate the other, an appropriation that either creates (metaphorical) slavery or reframes spousal duty as debt. It will take Augustine to articulate more clearly what desires and consumptions fuel this economy, and so to outline a subject of desire defined by a libido in need of regulation. ${ }^{1}$

Readers who turn to Aveux hoping to find an 'answer' to questions of agency (raised in Discipline and Punish) or an alternate theory of desire (to that critiqued in History of Sexuality vol. 1) will likely be disappointed. Much as Care of the Self (1988) and The Use of Pleasures (1990) contained long discussions of aphrodisia and gnothi seauton, with little hint of how to carry these readings forward, Aveux gives no explicit direction for how to interpret or work with the text. One possibility is to use it to explore those bonds that imperfectly overlap with legal relationships. After all, in interviews, Foucault argues that gay rights owe more to 'attitudes and patterns of behavior than to legal formulations' and that its practice needs to be one of 'constructing cultural forms' and '[fighting] against the impoverishment of the relational fabric' (1997b: pp. 157-158). Such relationships would need to amplify that expressive, veridictional self that 'particular form of subject that the law, that juridical thought, that judicial practice has never been able to assimilate' (2014, p. 152). Some passages in Aveux could be read so as to imagine contemporary forms of commitment not contained within existing legal relationships of marriage.

The stakes of Aveux change, however, when it is read as a genealogy rather than a prescriptive solution. Such a reading makes Aveux the hinge between an ancient Greek self-governance through relational practices, and the sixteenth century appropriation of sexuality as a site for governance. In doing so, it opens up (for a readerly audience if not those of early Christianity) the space of a spiritual subject not yet soldered to a juridical one - a claim radical in its time, but now more familiar from the intervening years of speculation.

Perhaps more ground is to be gained by thinking about the uneasy overlap forged between body and society, and the psychosocial relations on which it rests. Two points are striking. First, much like Freud, Foucault relies on desire and family structure to offer an account of what Leo Bersani has termed a 'promiscuous curiosity' (1995) that otherwise attaches wantonly and erratically. For Freud and 
Foucault, that promiscuous curiosity leads people out of themselves and into the world, and in Foucault's case, leaves readers wanting a stronger account of the psychic life of power, and what structures beyond those of religion, family and marriage might contain it. Indeed, and second, Foucault's emphasis on dispositifs of sexuality rather than sex covers over something quite different: namely, the fantasy of a different self as a desirable object. For Freud, the ahistorical presence of the id becomes part of a refusal to succumb to such narrativizing impulse; the id, and sexual impulses broadly, come to disorient and disrupt any effort to constitute the self. On this account, the process of self-constitution is inherently unstable and constantly undermined by its own desire to be otherwise. Foucault's move to situate the Christian libido genealogically challenges the shattering aspect of the psyche by stabilizing the libido through its historical emergence. However, by leaving unexplored those other relational modes hinted at earlier in this review, Foucault leaves the structure of desire itself intact. Yet such structures are not so easily abandoned or invented: they must contend with the aggression and destruction that attends any change in structuring order. New relational modes would require more than a different performativity - they would require a form of desire not premised on lack.

Unavoidably, Aveux must be read in a twenty-first century context very different from that of a France that refused to acknowledge Foucault's own death from AIDS, much less to condone homosexual relationships in his lifetime. In this sense, perhaps the clearest target of the volume is a Catholic, petit-bourgeois France still accustomed to think of sexuality as individualistic, marriage as rooted in procreation, and the repression of desire as natural to politics. Challenging these terms is indeed to seek out 'another form of life'.

\section{Note}

1 See Brown (1988).

\section{References}

Bersani, L. (1995) Is the Rectum a Grave? Chicago: University of Chicago Press.

Brown, P. (1988) The Body and Society: Men, Women, and Sexual Renunciation in Early Christianity. New York: Columbia University Press.

Foucault, M. (1988) The Care of the Self. vol. 3, trans. R. Hurley, New York: Vintage Books. Foucault, M. (1990) The Use of Pleasures. vol. 2, trans. R. Hurley, New York: Vintage Books.

Foucault, M. (1997a) Friendship as a Way of Life. In The Essential Works of Foucault: Ethics. vol. 1, trans. P, Rabinow, R. Hurley, (eds.) New York: New Press.

(C) 2019 Springer Nature Limited. 1470-8914 Contemporary Political Theory Vol. 19, S3, S192-S196 S195 
Foucault, M. (1997b) Sex, Power, and the Politics of Identity. In The Essential Works of Foucault: Ethics. vol. 1, trans. P, Rabinow, R. Hurley, (eds.) New York: New Press.

Foucault, M. (2014) Wrong-Doing, Truth-Telling: The Function of Avowal in Justice, trans. F. Bion, B. Harcourt, S. W. Sawyer, Chicago: University of Chicago Press.

Publisher's Note Springer Nature remains neutral with regard to jurisdictional claims in published maps and institutional affiliations.

Nancy Luxon

University of Minnesota-Twin Cities, Minneapolis, MN 55455, USA

luxon@umn.edu 